\title{
Urban citizenship(s) in Lisbon: examining the case of Mouraria
}

\section{André Carmo \& Ana Estevens}

To cite this article: André Carmo \& Ana Estevens (2017) Urban citizenship(s) in Lisbon: examining the case of Mouraria, Citizenship Studies, 21:4, 409-424, DOI: 10.1080/13621025.2017.1307602

To link to this article: https://doi.org/10.1080/13621025.2017.1307602

曲 Published online: 12 Apr 2017.

Submit your article to this journal ๔

Џll Article views: 191

View Crossmark data \lceil

Citing articles: 2 View citing articles 5 


\section{Urban citizenship(s) in Lisbon: examining the case of Mouraria}

\section{André Carmo and Ana Estevens}

Centre for Geographical Studies, Institute of Geography and Spatial Planning, Edifício IGOT, Lisbon, Portugal

\begin{abstract}
During the last couple of years it has been possible to witness the progressive commodification of Lisbon. The adoption of neoliberal strategies of urban development - oriented towards competitiveness and aimed at putting Lisbon at the forefront of the international metropolitan group - has contributed to the reshaping of its landscape. The organization of flagship events, privatization of public spaces and development of local policies oriented towards the promotion of creative industries, and the increasing relevance that various forms of tourism have assumed, illustrate well the path that has been followed. However, expressions of urban citizenship against this destructive trajectory have emerged, showing that the urban development of Lisbon is a contentious process and has to face multiple strategies of resistance. In this paper we look at three expressions of citizenship in Mouraria, a neighbourhood located in the historical centre of Lisbon, in which the tensions and contradictions between neoliberal urbanism and urban citizenship take place.
\end{abstract}

\section{ARTICLE HISTORY}

Received 10 April 2015

Accepted 15 December 2016

\section{KEYWORDS}

Lisbon; Mouraria; neoliberal urbanism; urban citizenship; c.e.m - Centro em

Movimento

\section{Introduction}

This paper examines urban citizenship in Lisbon, the tensions and conflicts that have emerged during the last couple of years, and the main outcomes vis-a-vis the current and future urban development of the city. Our starting point is the way urban citizenship has been unfolding in Lisbon, more precisely in a particular neighbourhood of its historical centre - Mouraria. From our point of view, it is in this area that the main characteristics, dynamics and trends of neoliberal urbanism are more intense and easily grasped (e.g. real estate and housing dynamics which are often heavily intervened in by international promoters and investors, gentrification of popular neighbourhoods and concomitant displacement of disadvantaged classes, intense touristification associated with the commodification of urban spaces, hyper cleanliness and securitization of the city).

The logic of profitability, commodification, market-competitiveness and entrepreneurship has become of utmost importance. Nevertheless, this process is not a fatality or a predetermined path to be followed by subjects deprived of any agency. The experiences examined seek to show how this structural contingency can be challenged and its underlying logic disrupted, making space for a more humanized and just urban space. From our 
perspective, the city is a 'battlefield' and the basic dimension of urban change relies on the antagonism between different groups, social classes and historical actors regarding the meanings of the urban world, and the dynamic relations existing between spatial form and social structure (Castells 2003). In sum, the urban world works as an important place for revolt and political action (Amin and Thrift 2004; Harvey 2012).

In what follows, a reflection upon three complementary and interwoven constitutive axes of urban citizenship - spaces, scales and political subjects - is carried out, providing the conceptual framework for the analysis. Next, some light is shed upon the way neoliberal urbanism has been implemented and developed in the Mouraria neighbourhood, identifying and discussing some of its most defining and iconic features. Lastly, we examine 'performative cleanings', 'routes' and 'micro dances' some of the most vivid and innovative examples of urban citizenship that have emerged in parallel to recent urban changes taking place in Mouraria.

\section{Urban citizenship: spaces, scales and political subjects}

The recognition that urban spaces are socially produced opens up a wide field of possibilities for citizenship intervention. The permanent reinvention of cities and concomitant transformation of the unjust logics underlying their production and the diverse uses of contemporary urban spaces are therefore related to urban citizenship. As an inherently political act performed by multiple connected institutions, organizations, movements and agents seeking to transform the unjust city, urban citizenship becomes absolutely crucial. In fact, it is through citizenship that people become, within (un)determined socio-spatial conditions, direct agents for the transformation of cities in which they constantly (re)inscribe their daily lives. In general, citizenship has been addressed from different perspectives, not always convergent (see Desforges, Jones, and Woods 2005; Dickinson et al. 2008; Gosewinkel 2010; Kurtz and Hankins 2005; Staeheli 2011). This paper does not aim at exhausting such a vast and fertile ground for socio-spatial analysis. The approach taken is limited to three conceptual-analytic axes that are seen as fundamental for its urban configuration: spaces, scales and political subjects.

The background for the analysis is the recognition that, for the last couple of decades, citizenship as a whole, not necessarily restricted to the urban, has been subject to profound transformations. For instance, looking at the European context, Borja (2000) underlined the role played by the crisis of the welfare state, structural and persistent unemployment, the lack of credibility and representativeness of political parties, the bureaucratization of public institutions, the multiplication of exclusions, the emergence of a new supranational political and economic frameworks accompanied by a significant transference of sovereignty to institutions other than the nation state, as well as the development of processes of differentiation and sub-national fracture, as processes that have been playing a relevant role in the transformation of citizenship. With a wider scope, Oliveira (2000), in turn, highlights four main transformative factors, namely: (i) a neoliberal wave that has been seeking to dismantle the welfare state; (ii) the end of a geopolitical bi-polarization forcing capitalist countries to show social concerns in order to counterpoise the Soviet model; (iii) a globalization of economy and culture that cuts across various geographical scales with effects that are felt, for instance, at the level of nationality and representation; (iv) an ever growing individualism, stimulated by the consumption society and the incessant and 
voracious commodification of everything, reducing citizenship to the sphere of consumption (see Lekakis 2013; Malpass et al. 2007; Pereira 2011).

All in all, contemporary models of citizenship seem to be failing, as the power of the common people, particularly in southern European countries such as Portugal that are being strongly influenced by supranational powers, is diminishing, while democracy is being eroded by austerity. Hence, profound uncertainties about some of the facets of citizenship that until recent times seemed to be relatively assured have arisen (see Carvalhais 2006). In this sense, new conceptions need to be devised in order to widen the horizons of socio-spatial imaginaries and renew political praxis. Urban citizenship, the operative concept privileged in this reflection, already translates as an effort to reconfigure and rethink the way citizenship is being exercised and looked at.

\section{Spaces: the city as privileged arena}

Several authors have stressed the historical legacy of urban citizenship and the way cities have been pivotal strategic arenas for the development of citizenship (see Barker 2009; Bauböck 2003; Beilharz 1996; Biehl 1998; Bookchin 1986, 2007; Ferreira 2003; Isin 1997, 2010; Pocock 1995). Interpersonal proximity and a high density of multiple and diverse contacts - both classical attributes of the urban society - seem to be some of the most important requirements for the development and expansion of citizenship (Low 2004).

For Holston and Appadurai (1999), large metropolises are privileged spaces when considering the conditions for social existence and the possibility of citizenship, for they are the sites where global forces (re)inscribe themselves and dense articulations of resources, people and projects take shape and develop there. In fact, it is there that the contradictions between formal and substantive citizenship become more intense. Whereas from a strictly formalist point of view (universal and de jure) citizenship is still articulated to the nation state, from a substantive one (concrete and de facto), related to the antagonisms and tensions involved in its construction, cities are the spaces where we can witness its constant reinvention (Garcia 1996; Gilbert and Dikeç 2008; Scott 1998).

By the same token, Amin and Thrift (2004) perceive the city - frantic social space made of flows and differences - as a privileged arena for non-traditional political experiences. Often small (molecular), fragmented, inconsistent and even trivial, they are meaningful because they can help to reinvent and amplify the political scope of human life as a field of creation, action and development (see Marceau 2013).

The collision between the traditional liberal conception of the universal-citizen and the heterogeneity and diversity of concrete political subjects that are instituted, organized and act in (and through) cities reveals itself as inevitable. At the core of this tension one finds migrations, a central dynamic regarding the social (re)construction of the city as a lived, dense, heterogeneous and volatile space, profoundly disruptive of the inherent homogeneity required by formal citizenship (see Capel 2003; Rogers 2000). In fact, the tensions coming from migrations force the state apparatus to react to new socio-spatial conditions promoting the creation of new legal rights outside the normative and institutional scope and already consolidated frameworks. From this stance, citizenship reconfigures itself as a dynamic claim for rights - the right to have rights - and not as status. Contrary to what one could be lead to believe, based on the new morphologies of public spheres, hybrid virtual communities, diasporic and transnational networks, and other combinations of non-spatial sovereignty, 
cities do not become irrelevant. As spaces of tension and asymmetric power relations or, as Isin (2002) puts it, as 'battlefields' through which different social groups define their identities, claim their causes, conduct their struggles and articulate citizenship rights and duties, cities become the most important spaces for the reconstruction of citizenship (see Stevenson 2003).

Despite the contemporary reinforcement of atomized individuals, consumers and citizens of the world market that weakens the classical notion of the citizen as political subject and driving force of social change, urban spaces have been, in fact, placed at the centre of the citizenship process due to their strategic potential. Likewise, most tensions, dilemmas and contradictions inherent to the exercise of citizenship emerge and become more vivid in urban spaces (see Parazelli 2001).

\section{Scales: the multi-scalar tendency}

By considering that the urban is a socio-spatial complex that transcends the physical city, incorporating networks of actors and systems involved in multiple relations operating at different levels, we seek to escape the 'local trap', i.e. the tendency to prioritize the local scale vis-a-vis others, hindering the construction of multi-scalar strategies (Purcell 2006, 2008). Contemporary cities incorporate highly complex organizations, rationalities, institutions, processes and norms with different levels of political legitimacy that are simultaneously 'de-territorialized' (going way beyond the city limits), and 're-territorialized' (constantly negotiating with limits other than their own).

The perception that urban citizenship is complex led to the increasing recognition of its multi-scalar nature, being shaped by conditions, processes and institutions that, while operating at the local, national and global scales, build multiple forms and differentiated expressions of citizenship (see Martin, Lapalme, and Gutman 2013). This does not mean that the citizenship-state nexus has become utterly irrelevant, but only that the national scale is not the only one where citizenship is produced and invested with meaning. The spatiality of urban citizenship goes way beyond the traditional contexts of government, towards neighbourhoods, working places and public and domestic spaces, in sum, to all social spaces that somehow influence and configure urban struggles and praxis. Hence, the processes of formation of subjectivities or political identities, i.e. the way subjects understand themselves vis-a-vis their communities, the questions they raise and the type of political actions they decide to take, become more relevant than the formal conditions of belonging to a certain community (see Clarke 2008; DeFilippis and North 2004; Staeheli 2008).

For Purcell (2003) there is now growing evidence that citizenship is 'glocalized' and operates at multiple scales (transnational, regional, local, etc.) in a process that subverts and counters the modern hegemony of the national scale, creating opportunities for the emergence of expressions of citizenship articulating at other scales (e.g. World Social Forum, Occupy Wall Street, Arab Spring). New configurations of citizenship are not circumscribed to sovereign states. The Westphalian narrative, according to which citizenship is a unique condition exclusively linked to sovereign states, is thus increasingly questioned. It is challenged to the extent that the nation state is no longer the only reference for defining political identity and loyalty. It is possible to acknowledge the emergence of other political subjectivities and communities based on geography, ethnicity, gender, sexual orientation and human condition, all as a potential basis for the construction of citizenship (see Cupers 2005). 
When discussing urban citizenship, the question of scale is decisive. For Isin (2007), 'scalar thought', itself a product of social and political power relations, emerges from the modern state necessity to regulate, control and govern the multiple flows of social reality it seeks to apprehend and capture. In fact, the modern institution of the state as supreme imaginary subject created a scalar relation - historical, exclusive and hierarchical - between the state and other political subjects/communities. Obviously, as a legal status citizenship is inextricably anchored to a territory in relation to which such condition is ascribed and validated. Once we start to problematize and refocus the question of rights and duties towards concrete social, cultural, ethical, aesthetic and political spaces, scalar thought shows its limits and often we see that the socio-spatial processes taking place in a certain city, state or nation do not coincide with their boundaries.

\section{Political subjects: the growing diversity of citizens}

From the 1960s onwards, and in direct relation to the transition towards a flexible accumulation regime and concomitant loss of vitality within the trade union movement, new political subjectivities articulated around matters such as sexual orientation, 'race', environment or consumption emerged. Irazábal (2008) underlines the growing relevance of a wide array of citizenship expressions forged around themes that were relatively invisible (e.g. sexuality, ethnicity, age). Adjectives such as multi-level, nomad, performative and sustainable are now used to represent new configurations of citizenship shedding some light upon its multifaceted and dynamic nature.

The construction of urban citizenship also involves the attempt to resist the exclusion and invisibility that dominant social groups ascribe to 'others'. As Isin $(1997,118)$ suggests, 'the emergence of citizenship as a political space can only happen when the power of a dominating class is effectively challenged'. Such a process has always implied that those that are effectively denied a just place in the social urban fabric rise up and demand their voices to be heard and recognized by those that possess power and exercise control and social domination (see Rancière 1999; Zizek 2006). As Isin (2002, 2005) highlights, citizenship exists in the precise moment when the supposed acceptance of dominant virtues is questioned and its arbitrariness unconcealed; when the established hierarchy is reverted, redefined and rethought; when those that are dominated, stigmatized, oppressed and marginalized act collectively and become constituted as political subjects. Citizenship exists when it is performed and political subjects develop, demonstrate a predisposition for action, a will to exert freedom, and participate in conflict - in sum, assume the dignity of considering themselves as equals (Borja 2003).

The political subjects of urban citizenship are increasingly complex, plural and diversified. Through the critical analysis of innumerable transformations verified in contemporary societies, such as for instance, the extraordinary development of information technologies, some authors have drawn our attention to new forms of cognitive, immaterial and bio political production (Berardi 2005, 2009; Hardt and Negri 2000, 2005; Matos 2012), a strengthening of the precariat (see Antunes 2003, 2011; Antunes and Alves 2004; Harvey and Wachsmuth 2012; Standing 2011) and emergence of new forms of organization and political intervention (see Graeber 2002, 2009; Mendes 2008; Norris 2002; Purcell 2013).

In the contemporary urban world, new political subjects, new subjectivities and identities, new loci of struggle and new scales of identification are produced. Linked to a wide array 
of claims, practices and acts through which subjects become political beings, revealing and activating what previously had remained silent and invisible, thus modifying the political landscape and widening the horizon of future possibilities, urban citizenship allows the transformation of cities and the emergence of new political subjectivities.

\section{(Re)branding Lisbon or Mouraria ${ }^{\circledR}$ unleashed}

In 2015, Lisbon won the European Entrepreneurial Region award. It is a city where it is increasingly harder to travel around due to the profusion of tuk-tuks, but where it is now easier to find a place to spend a night. This is because more and more residents choose to rent their houses for touristic activities as they themselves have started to live in the outskirts of the city. In addition, the increase of housing rent has caused a lot of problems for people looking for a place to live. Local commerce has been systematically destroyed due to its incapacity to resist the current economic decline. In addition, everything that is traditional and typical becomes ever more exclusive and gourmet shops are growing at a fast pace. From time to time, mega-events promoted by large companies temporarily privatize public spaces and limit their collective (and free) use. Today, Lisbon is a city of paradoxes and contradictions, along with other European cities. Arguably, a city that is made for capital, not for people. In sum, Lisbon is now a city whose urban landscape has been profoundly reshaped by neoliberal urbanism and where a multi-scalar strategy is evident. Distinct conditions, processes, institutions, organizations, movements and agents build multiple forms and differentiated expressions of citizenship.

Lisbon has changed its model of development and clearly adopted a neoliberal approach towards city change. In this sense, neoliberal urbanism is not an abstract ideological device somehow floating a few metres above the ground, but an anchored and deeply embedded socio-spatial process, consisting of distinctive praxes and discourses, which (re)inscribes itself in concrete urban spaces, reshaping the landscape of Lisbon in the favour of private capital. In fact, as Colombo and Porcu $(2014,2)$ point out, urban transformations 'have a strong dependence on the context whose specificities they reflect, but also the conflicts and compromises implemented to guarantee a favourable climate for private capital'. It is one of the most relevant European cities when we think about touristic places: Lisbon is a destination that is increasingly in vogue. The 'Lisbon brand', like the 'Barcelona model', is focused on identity, traditions, nostalgia, cosmopolitan life, diversity and modernity, memory and the celebration of the city, often based on placebo dependency, i.e. a strong reliance on 'symbolically resonant, market oriented and low-cost initiatives that marry aspirational goals (creativity, sustainability, liveability, etc.) with projects that work with the grain of localized incentives and business-as-usual interests' (Peck 2012, 648). Likewise, it fits into the competitive and efficient city perspective which attracts investment and creates the image of an ideal and safe city. To Graça Fonseca, councillor in the Lisbon municipality, the existence of a brand is clear. On 11 February 2013, she stated for the Imagens de Marca website that the evident global competition between cities for investment, talent, money or infrastructure requires 'a story that unites the various players and the various partners of the city. It is important to adopt the city branding strategy'. The connection of the 'Lisbon brand' to tourism is quite evident and it is projected all over the city. Lisbon has been the subject of several policies that focused on changing its image. Centred on renewal processes 

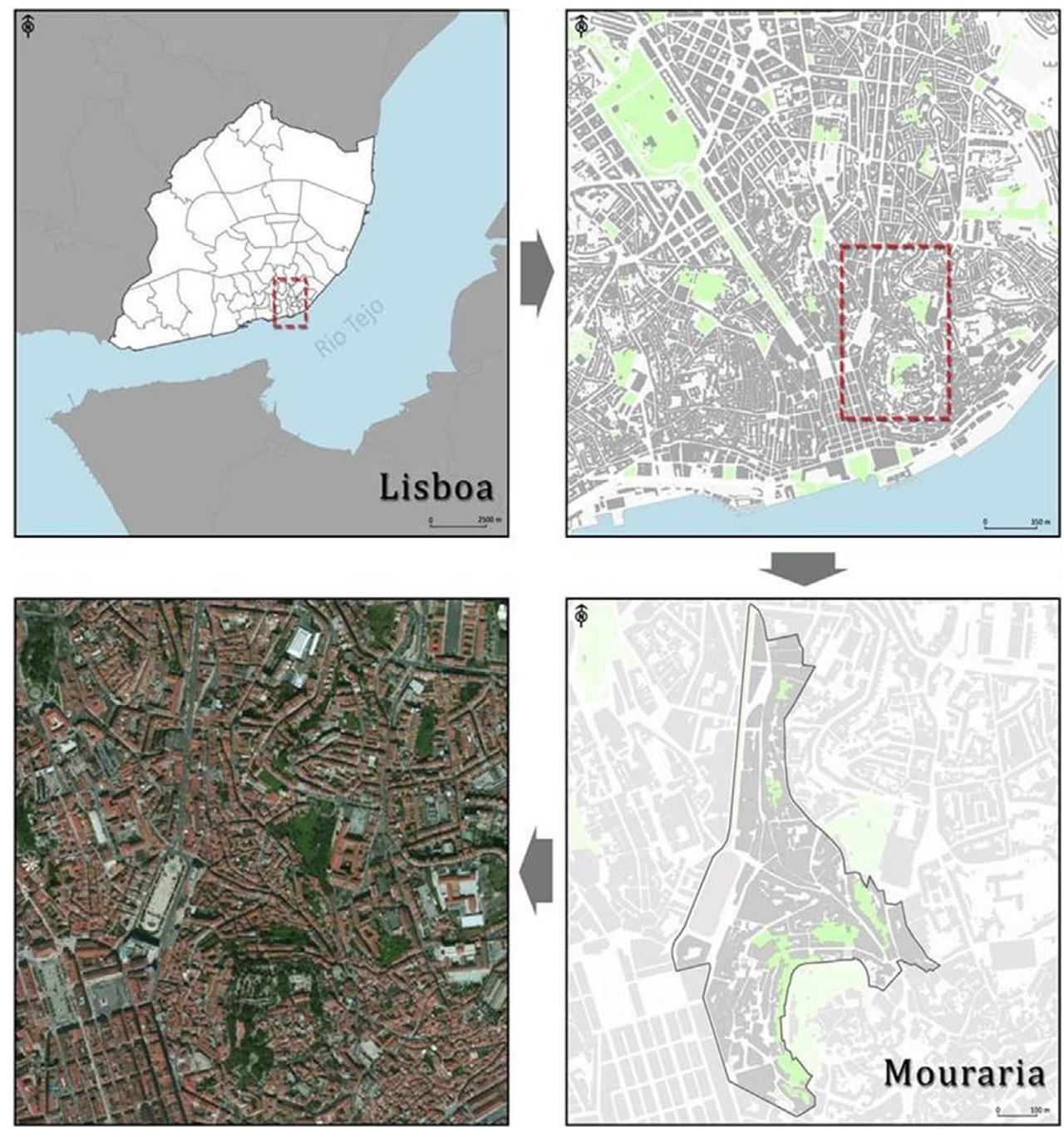

Figure 1. Mouraria neighbourhood. Source: image elaborated by Leandro Gabriel (2014).

and, subsequently, urban regeneration, these policies have favoured the aesthetic transformation of a city that wants to be 'typical and popular', but also cosmopolitan and dynamic.

Mouraria is one of the most typical and oldest neighbourhoods of the city of Lisbon (Figure 1). Located in the city centre, Mouraria (meaning Moorish neighbourhood), was the territory that was assigned to the Moors and Jews after the Christian occupation in 1147. The Arab urban planning legacy is still visible in its narrow streets, courtyards and alleys. In this sense, it can be seen as an example of an organic urban fabric. Furthermore, talking about the Moorish quarter implies speaking of the characteristics of a popular neighbourhood of Lisbon, one of the 'strong emblems of Lisbon' (Cordeiro 2001, 8) and its inhabitants. For Matos (1999), popular neighbourhoods are urban complexes that are configured externally as individualized and almost autonomous entities, and which inside have great diversity in terms of occupied space and building systems. In these contexts, 
social relations or socio-cultural dynamics remain very significant and defining features. Located in the centre of Lisbon, Mouraria is usually associated with degradation, crime, poverty, shabbiness or marginality that marks an extension of a certain centre-peripery segregation and, in a sense, the margin. In this territory, the construction of an invented and enduring tradition that has been appropriated by different discourses, seems evident. There is also a certain performative drama centred on a 'fatal destiny' associated to fado and popular street carnivals but also to poverty and misery.

Mouraria is a complex geographical context, imbued with constructed images and symbols. It has repeatedly experienced stigmatization and segregationist prejudices. It has social representations projected on a stereotyped environment that, over the years, created the increasingly marginal, ugly, dangerous and unhealthy character of the neighbourhood, in which some segments of the population with economic difficulties were particularly affected. Prostitution, poverty, social injustice, drug addiction, alcoholism or marginalization are just some aspects of the processes/phenomena consistently problematic for this neighbourhood. Others are appearing on every street and relate to new social, cultural and urban dynamics. In a broader sense, these new dynamics are related to the policies implemented all over the city intending to engage it within the context of global cities: during the period of the dictatorship, the assumptions were to sanitize the historic neighbourhood and demolitions were common in Mouraria; in the years that followed the revolution (1974), the concerns focused on the rehabilitation of buildings and the inhabitants played a key role in decision-making; later, in the 1990s, the aesthetic concerns and the market became the main objective, without much attention to social concerns; and more recently, the plans and the projects seek to change the 'bad name' of the neighbourhood, as will be seen below. Arguably, this neighbourhood, as will be suggested later, can be constituted a privileged space for the development of citizenship.

Some characteristics of the neighbourhood help us to further understand the Mouraria context within the city of Lisbon, namely, the precarious conditions of housing, especially the fact that many houses do not even have a bathroom or shower, and a relatively old population with low levels of education (in Mouraria 25\% of the population has only the primary education). Furthermore, it is also possible to acknowledge a significant decrease in the number of residents between 1981 and 2011 (-53\%), as a result of ageing demographics and gradual displacement brought by slow-development gentrification processes.

Hence, over the years, the neighbourhood of Mouraria has been modified, both by the arrival of new residents, mostly immigrants, and its physical transformation. However, there is an imagery linked to this place: to think of Mouraria brings to mind a diverse array of images replicating the idea of tradition, typicality and popular culture, liminality and danger, multiculturalism, multi-ethnicity or heritage (Menezes 2012). On one hand there are interconnections between segregation and stigmatization processes. On the other, there are a number of attempts to reinvent a certain folk imagery of the neighbourhood. In relation to this imaginary there are two elements that must be taken into account. One is the fado, centred on the image of a woman: the Severa. The other is the popular street carnivals related to the city's parties. These are important folk symbols of identity belonging to the neighbourhood that mark and claim the identity of Mouraria and have been and are also important in relation to the changes over the years. Currently, they seek to change the image of the neighbourhood, making it more attractive for touristic activities. 
When looking at the traditional Mouraria one meets the Severa myth - stylized as a fado singer - which holds a significant sociological role. This woman became monumentaliized, transforming her into a kind of human representation of fado. This performative celebration of the life of Severa became an 'ontological view of the fado origin - until now marked by an evolutionist and infusionist position that defined it as a gender "mestizo" with strong African influences that would come to Portugal via Brazil" (Marinho and Sardo 2012, 88). The 'Estado Novo' (dictatorship period in Portugal) appropriated fado as a national song, trying to make it one of its main propaganda tools and the imagined figure Severa gained significance. However, verifying the impossibility to control the lyrics and the songs, the 'Estado Novo' tried to legitimize and frame this music genre through its cultural policies.

The popular street carnivals, with the city parties (taking place in 12th June of each year), had their origin in the 1930s and their characteristics have remained until the present day, with only minor changes occurring. The tradition of popular street carnivals organized by the dictatorship formed a popular and parochial identity (Carvalho 1991; Cordeiro 2003; Frúgoli 2014). However, there is a situation that Carvalho (Carvalho 1991, 42) considers peculiar: despite the creation of the tradition of the popular street carnivals by the dominant fascist regime, it has been the popular classes who have allowed it to continue. In fact, he suggests, popular street carnivals or the 'thrones' of St. Anthony are traditions that were appropriated by 'a propaganda action of Salazar' relating to representation and identity practices. Actually the reinvention of this folk imagery of the neighbourhood, with the traditional fado and the popular street carnivals, was adopted by a cultural policy of the city to ameliorate this stigmatized place.

Recently, Mouraria was the locus of profound urban changes. Through the Programme of Action of the National Strategic Framework (PA-QREN Mouraria) 'Cities within the city', for instance, various urban interventions were carried out in the neighbourhood. With QREN financing for this historic neighbourhood of the city center, considered degraded and in poor condition, various mechanisms and programs with many actors were employed. The PA-QREN Mouraria was not implemented in an isolated neighbourhood, many projects were elapsing in its orbit. However, the confusing and dense network is extensive and with great complexity, hindering a comprehensive understanding of the entire process. Arguably, it was not conceived in order to foster the development of spaces, dynamics and mechanisms of citizenship. In fact, it configures a space of various tensions and asymmetric power relations, that necessarily invisibilizes stigmatization and marginalization processes that are deeply inscribed into the socio-urban fabric of the neighbourhood.

Parallel to this process, public space is being privatized or taken over by private interests. Two of the squares of the neighbourhood, Intendente Pina Manique Square and Martim Moniz Square, suffered considerable transformations. While in the first case the rehabilitation of the space helped the creation of new retail spaces, in the second, the Lisbon municipality sold the space to a company that already owns other spaces in the city. The contradictions stemming out of this process of privatization are well illustrated by the results of a survey made to residents in Mouraria (Rucas Project PTDC/CSGEO/115603/2009), showing that about $79 \%$ of the neighbourhood's population confirmed that they usually use public space for walking (42\%), leisure (28\%) or transit (24\%). When questioned about which spaces they most commonly used, Intendente Pina Manique Square and Martim Moniz Square were most frequently cited (both over 20\%). However, when asked if they visited the market that was established in Martim Moniz Square, 81\% answered that they 
do not use that space because they: 'dislike' it (25\%); are 'just passing through' (18\%) or 'do not identify with the place' (7\%). It can be argued that there is a nuanced process of exclusion/displacement, as inhabitants of the neighbourhood do not feel comfortable or welcomed to use this 'public' space. The high prices in this 'new space' could be another factor excluding the low-income population of the Mouraria. On the other hand, other people - middle classes, entrepreneurs, bobos and hipsters - have been drawn in, highlighting the paradoxical nature of gentrification processes, profoundly disruptive of urban environments and daily life routines. The consequence of all these changes in Mouraria has been the promotion of real estate and housing dynamics which are often heavily intervened in by international promoters and investors, the gentrification and concomitant displacement of disadvantaged classes, an intense touristification associated with the commodification of urban spaces and a hyper cleanliness and securitization of the city. By the same token, immigrants, gentrifiers or elderly persons interact with an institutional fabric responsible for the territorial inscription of hierarchies constraining people's capacity to act collectively.

\section{'Performative cleanings', 'routes', and 'micro dances', or the art(s) of urban citizenship in Mouraria}

In the context of recent changes in Mouraria, as referred to earlier, artistic and cultural creation has gained a prominent role. The presence of artists and 'creative' people in the neighbourhood was appropriated by several different projects. Relating to the multicultural aspect of the neighbourhood, various concepts of cultural events and one symbolic narrative with a sense of ownership was constructed around the vibrant cultural nature of the place. Interethnic cooperation, memory, image and a certain identity are valued in these events as vital elements of a practice that aims to attract people to the neighbourhood by trying to change the stigma associated with it. To Zukin (1995) this type of cultural policy is seen as 'a powerful means of controlling the city'. The 'new types of "mixed use" policies are deployed to "improve" poor neighbourhoods through influx of more affluent people, and area based social programs are applied to "blighted" neighbourhoods presumably to stem their downward spiral' (Mayer 2013). However, the intercultural life of the neighbourhood can be an important strategic axis for the construction of stronger citizenship dynamics in Mouraria. Notwithstanding, it is important to take into account the specific needs and desires of residents, otherwise, there is a risk of their being used merely as figurative objects, destitute of agency.

If on the one hand we witness a tendency to homogenize and replicate the processes that take place globally by trying to privatize, control and securitize, thus reinforcing the atomization of people, reduced to consumers and citizens of a world market; on the other, there are signs of resistance producing friction in the mechanisms created by privatization and control. It was against this background that a collective of artistic creation and research - Centro em Movimento (c.e.m.) - has developed collective creative possibilities for urban citizenship in Mouraria, strengthening relations, knowledge and critical thinking in the neighbourhood, (re)inventing and (re)constructing space. C.e.m. can be seen as the 'others' that resist exclusion and, with their invisible practices give rise to citizenship as a political praxis.

Not looking at art as a concept sealed in its own space, it is considered that 'art' opens paths and proposals for action, dialogue, conflict and negotiation, which even though not 
evident at the outset, are gaining more relevance. These proposals can produce denser and more consistent political subjects. The crossing of knowledge or proximity of social relations enhances the opening of new possibilities, converting them often in new connections and empowering the existence of the place and the people who inhabit it. These urban citizenship acts penetrate deep into the social fabric and everyday life, not willing, in principle, to change their momentum but imbuing them with critical awareness. They reconfigure the way places are experienced, not denying the possibility of transformation that is subsequently created: 'isn't this art's political power?' (Rolnik 2010,21). It is a political action that reconfigures the collective landscape, generating unexpected atmospheres and reverting hierarchies. Like noted by Lemos in the c.r.u. | Corpo Resistente na Urbe website,

as we move through art, our intention is not to save or solve people's lives, but we know that the presence in continuity of a body in the dance state, in constant listening and creation, changes the context generating unexpected atmospheres, reconfiguring the collective landscape, transforming it, and being with her permanently transformed.

With the work of the c.e.m., which is developed by people of all ages and in different places of the neighbourhood, it was possible to observe different dynamics of learning, questioning, criticism and resistance during the period between 2011 and 2014, which coincided with the most severe phase of the recent crisis. While the projects developed under the PA-QREN Mouraria were based on mainstream assumptions, linked to a dynamic that represented a dominant view of creating a cosmopolitan, multicultural, diverse and creative city, the c.e.m. developed its work based on a more nuanced account of the neighbourhood's reality: stigmatized and marginalized population. In the context of this paper we will focus on tree actions of c.e.m.: 'performative cleanings', 'routes' and 'micro dances'. These actions reflect and recognize the fact that urban spaces are socially produced and open possibilities for citizenship intervention.

'Performative cleanings' that were taking place every Friday from January to July, proposed to

simply clean a street floor area for one hour in tuned action among all participants, each person a ground bit (...) Cleaning the street floor, for those do not do it by profession leads in fact to see in detail what more "common" and "shared" exists in the city, the ground we walk on. Cleaning is caring, caring is paying attention. (Traquino 2011, 51)

By the same token, 'cleaning lets me dwell on details' said Gracinda, one of the Lisbon Municipality public space cleaners.

'Performative cleanings' can be considered as moments of attention to the details of the streets, the squares and the corners. Practising the art of being in the street hampers abandonment and reduces indifference for the place. Simply take a piece of town and invite anyone who wants to join to wash stones, thus encouraging encounters with those who live there or who pass through the streets. 'Performative cleanings' are moments of being together, an instance of another way of being in public space, where a place of transit and forgetfulness can be transformed into a landscape of attention, care and detail.

During the same period, tracing 'routes', itineraries of Lisbon, and more concretely in Mouraria, that took place once a week for five hours with people of c.e.m, was other street action of c.e.m. During the period between 2011 and 2014, it was possible to follow the changes that were taking place in the neighbourhood: beautification of public space, social programs to 'blind' inhabitants, marketing strategies to attract new investment, privatization of public space, replacement of older people by young people, buildings for sale, buildings 
in rehabilitation or new commerce. These hegemonic changes and the cannibalization of daily life had disastrous consequences in the neighbourhood that were registered and documented in the 'routes'. But, sometimes, in the 'routes' it was possible to see people and micro spaces (e.g. the owner of a laundry providing support to street prostitutes) that showed the emergence of others powers.

'Micro dances' were moving dances that took place in small places. In these dances, all the people, those who were by the window or passing on the street, were invited to join in and dance. A sharing environment was created through the passage of the 'micro dances'. These little dances that went through the streets of Mouraria, created micro spaces where people were able to talk and/or share their stories through dance, creating conditions for social existence and assuming themselves as equals, without hierarchies or dominant groups. It was one dance for all. This process to change power relations and political subjects is dynamic and slow. However, the possibility to reconfigure urban spaces with democratic participation and critical perspectives emerges.

\section{Conclusion}

Mouraria as a pivotal context for the urban neoliberalization process currently taking place in Lisbon. Gentrification, rebranding, socio-economic polarization and deregulation in housing market are all dynamics that converge in this specific locale and reconfigure it according to the interests of investors and real estate promoters, hence, against the popular classes that helped to shape throughout the years the social materiality of the neighbourhood. 'Performative cleanings', 'routes' and 'micro dances' are a good example on how to practice subversion at the urban scale, using institutional and mainstream frameworks turning them upside down and creating collective actions of urban citizenship that reconfigure urban spaces, making them more democratic, free and human.

In this context, spaces of artistic creation are particularly important and are a form of urban citizenship. Art cannot, or should not, be considered individually in the context of city production. Art is one more political dimension which should be considered as a whole, even though it was implicated in a strategic vision for the city implicit in public policy applied to Mouraria. Art is usually seen in two distinct poles: art for the masses or art for the elites. In the case of Mouraria, a closer approach helped to understand the processes and the dynamics that collectively produced operating artistic expressions of citizenship, involving residents and struggling against displacement and exclusion.

\section{Disclosure statement}

No potential conflict of interest was reported by the authors.

\section{Funding}

This work was supported by Fundação para a Ciência e a Tecnologia, the Real Utopias in Socially Creative Spaces (RUcaS) [PTDC/CS-GEO/115603/2009]. 


\section{References}

Amin, Ash, and Nigel Thrift. 2004. “The 'Emancipatory' City.” In The Emancipatory City: Paradoxes and Possibilities, edited by Loretta Lees, 231-235. London: Sage.

Antunes, Ricardo. 2003. "O carácter polissêmico e multifacetado do mundo do trabalho [The polysemous and multifaceted character of the world of work]." Trabalho, Educação e Saúde 1 (2): 229-237. doi:10.1590/S1981-77462003000200004.

Antunes, Ricardo. 2011. "Os modos de ser da informalidade: rumo a uma nova era da precarização estrutural do trabalho? [Informal ways of being: towards a new era of structural precariousness of work?]” Serviço Social \& Sociedade 107: 495-419. doi:10.1590/S0101-66282011000300002.

Antunes, Ricardo, and Giovanni Alves. 2004. "As mutações no mundo do trabalho na era da mundialização do capital. [Mutations in the world of work in the era of the globalization of capital]" Educação \& Sociedade 25 (87): 335-351.

Barker, Derek W. M. 2009. Tragedy and Citizenship: Conflict, Reconciliation, and Democracy from Haemon to Hegel. New York: State University of New York Press.

Bauböck, Rainer. 2003. "Reinventing Urban Citizenship." Citizenship Studies 7 (2): 139-160. doi:10 .1080/1362102032000065946.

Beilharz, Peter. 1996. “Citizens of Cities.” Thesis Eleven 46: 89-95. doi:10.1177/0725513696046000005.

Berardi, Franco. 2005. "What does Cognitariat Mean? Work, Desire and Depression." Cultural Studies Review 11 (2): 57-63.

Berardi, Franco. 2009. Precarious Rhapsody: Semiocapitalism and the Pathologies of the Post-alpha Generation. London: Minor Compositions.

Biehl, Janet. 1998. The Politics of Social Ecology: Libertarian Municipalism. Montreal: Black Rose Books.

Bookchin, Murray. 1986. The Limits of the City. Montreal: Black Rose Books.

Bookchin, Murray. 2007. Social Ecology and Communalism. Oakland: AK Press.

Borja, Jordi. 2000. "The Citizenship Question and the Challenge of Globalization: The European Context." City 4 (1): 43-52. doi:10.1080/713656996.

Borja, Jordi. 2003. La Ciudad Conquistada [The Conquered City]. Madrid: Alianza Editorial.

Capel, Horacio. 2003. "A Modo de Introducción - Los Problemas de las Ciudades: Urbs, Civitas y Polis [A Mode of Introduction - Problems of Cities: Urbs, Civitas and Polis]." In Mediterráneo Económico (Ciudades, arquitectura y espacio urbano), coordinated by Horacio Capel, 9-22. Almería: Instituto Cajamar.

Carvalhais, Isabel E. 2006. "Condição pós-nacional da cidadania política: Pensar a integração de residentes não-nacionais em Portugal. [Post-national condition of political citizenship: Thinking about the integration of non-national residents in Portugal]" Sociologia, Problemas e Práticas 50: 109-130.

Carvalho, Ruben. 1991. A vertente política e a vertente popular das Festas de Lisboa [The political and the popular side of the Lisbon Festivities]. In Festas de Lisboa, edited by Comissão Consultiva Festas, 1990, 26-55. Lisboa: Livros Horizonte.

Castells, Manuel. 2003. “The Process of Urban Social Change.” In Designing Cities: Critical Readings in Urban Design, edited by Alexander Cuthbert, 23-27. Oxford: Blackwell.

Clarke, Susan E. 2008. "Community and Problematic Citizenship." Political Geography 27: 22-28. doi:10.1016/j.polgeo.2007.09.003.

Colombo, Dario, and Manuela Porcu. 2014. "Provincial Neoliberalism: A Case Study." Justice Spatiale | Spatial Justice 6: 1-15.

Cordeiro, Graça Í. 2001. “Territórios e Identidades: sobre escalas de organização sócio-espacial num bairro de Lisboa. [Territories and Identities: about scales of socio-spatial organization in a neighborhood of Lisbon]" Revista de Estudos Históricos 28: 125-142.

Cordeiro, Graça Í. 2003. "Uma certa ideia de cidade: popular, bairrista, pitoresca. [A certain idea of the city: popular, from the neigbourhood, picturesque]" Sociologia XIII: 185-199.

Cupers, Kenny. 2005. "Towards a Nomadic Geography: Rethinking Space and Identity for the Potentials of Progressive Politics in the Contemporary City." International Journal of Urban and Regional Research 29 (4): 729-739. 
DeFilippis, James, and Peter North. 2004. "The Emancipatory Community? Place, Politics and Collective Action in Cities." In The Emancipatory City? Paradoxes and Possibilities, edited by Loretta Lees, 72-88. London: Sage.

Desforges, Luke, Rhys Jones, and Mike Woods. 2005. "New Geographies of Citizenship." Citizenship Studies 9 (5): 439-451. doi:10.1080/13621020500301213.

Dickinson, Jen, Max J. Andrucki, Emma Rawlins, Daniel Hale, and Victoria Cook. 2008. "Introduction: Geographies of Everyday Citizenship." ACME: An International E-Journal for Critical Geographies 7(2): $100-112$.

England, Kim, and Kevin Ward. 2007. "Conclusion: Reflections on Neoliberalizations." In Neoliberalization: States, Networks, Peoples, edited by Kim England and Kevin Ward, 248-262. Oxford: Blackwell.

Ferreira, Vítor M. 2003. "Movimento, urbanidade e cidadania. [Movement, urbanity and citizenship]" In Novas Formas de Mobilização Popular, coordinated by José Rebelo, 51-61. Porto: Campo das Letras.

Frúgoli, Heitor. 2014. "Festas populares em Lisboa: uma etnografia a partir do Bairro Alto. [Popular festivities in Lisbon: an ethnography from the Bairro Alto]" Etnográfica 18 (1): 77-98.

Garcia, Soledad. 1996. "Cities and Citizenship." International Journal of Urban and Regional Research 20 (1): 7-21. doi:10.1111/j.1468-2427.1996.tb00298.x.

Gilbert, Liette, and Mustapha Dikeç. 2008. "Right to the City: Politics of Citizenship." In Space, Difference, Everyday Life: Reading Henri Lefebvre, edited by Kanishka Goonewardena, Stefan Kipfer, Richard Milgrom and Christian Schmid, 250-263. New York: Routledge.

Gosewinkel, Dieter. 2010. “Citizenship." In International Encyclopedia of Civil Society, edited by Helmut K. Anheier and Stefan Toepler, 140-145. New York: Springer.

Graeber, David. 2002. “The New Anarchists.” New Left Review 13: 61-73.

Graeber, David. 2009. Direct Action: An Ethnography. Edinburgh: AK Press.

Hardt, Michael, and Antonio Negri. 2000. Empire. Cambridge: Harvard University Press.

Hardt, Michael, and Antonio Negri. 2005. Multitude: War and Democracy in the Age of Empire. London: Penguin Books.

Harvey, David. 2012. Rebel Cities: From the Right to the City to the Urban Revolution. London: Verso. Harvey, David, and David Wachsmuth. 2012. "What is to be Done? And Who the Hell is Going to Do It?" In Cities for People, Not for Profit: Critical Urban Theory and the Right to the City, edited by Neil Brenner, Peter Marcuse and Margit Mayer, 264-274. Abingdon: Routledge.

Holston, James, and Arjun Appadurai. 1999. "Cities and Citizenship." In Cities and Citizenship, edited by James Holston, 1-18. Durham: Duke University Press.

Irazábal, Clara. 2008. "Citizenship, Democracy and Public Space in Latin America." In Ordinary Places, Extraordinary Events: Citizenship, Democracy and Public Space in Latin America, edited by Clara Irazábal, 11-34. London: Routledge.

Isin, Engin F. 1997. "Who is the New Citizen? Towards a Genealogy." Citizenship Studies 1 (1): 115-132. doi:10.1080/13621029708420650.

Isin, Engin F. 2002. Being Political: Genealogies of Citizenship. Minneapolis: University of Minnesota Press.

Isin, Engin F. 2005. “Engaging, Being, Political.” Political Geography 24: 373-387. doi:10.1016/j. polgeo.2004.07.002.

Isin, Engin F. 2007. "City.State: Critique of Scalar Thought." Citizenship Studies 11 (2): 211-228. doi:10.1080/13621020701262644.

Isin, Engin F. 2010. "Citizenship." In Encyclopedia of Urban Studies, edited by Ray Hutchinson, 144147. London: Sage.

Kurtz, Hilda, and Katherine Hankins. 2005. "Guest Editorial: Geographies of Citizenship." Space and Polity 9 (1): 1-8. doi:10.1080/14742830500078500.

Lekakis, Eleftheria J. 2013. "A Liquid Politics? Conceptualising the Politics of Fair Trade Consumption and Consumer Citizenship." Ephemera: theory \& politics in organization 13(2): 317-338.

Low, Murray. 2004. "Cities as Spaces of Democracy: Complexity, Scale and Governance." In Spaces of Democracy: Geographical Perspectives on Citizenship, Participation and Representation, edited by Clive Barnett and Murray Low, 129-146. London: Sage. 
Malpass, Alice, Clive Barnett, Nick Clarke, and Paul Cloke. 2007. "Problematizing Choice: Responsible Consumers and Sceptical Citizens." In Governance, Consumers and Citizens: Agency and Resistance in Contemporary Politics, edited by Mark Bevir and Frank Trentmann, 231-256. New York: Palgrave Macmillan.

Marceau, Stéphane Guimont. 2013. "Le Wakiponi mobile: conquête d’un nouveau territoire de citoyenneté pour de jeunes autochtones [Mobile Wakiponi: conquering a new territory of citizenship for autochthonous youth].” ACME: An International E-Journal for Critical Geographies 12(3): 551-575.

Marinho, Helena, and Susana Sardo. 2012. "Construir a nação com música: o protagonismo do compositor Frederico de Freitas no primeiro fonofilme português: A Severa. [Building the nation with music: the protagonism of the composer Frederico de Freitas in the first Portuguese phonofilme: A Severa]" Revista Música Hodie 12(1): 87-103.

Martin, Patricia, Annie Lapalme, and Roffe Mayra Gutman. 2013. "Réfugiés et demandeurs d’asile mexicains à Montréal: actes de citoyenneté au sein de l’espace nord-américain? [Mexican Refugees and Asylum Seekers in Montreal: Citizenship in North America?]" ACME: An International E-Journal for Critical Geographies 12(3): 603-628.

Matos, José Luís. 1999. Lisboa Islâmica [Islamic Lisboa]. Lisboa: Instituto Camões.

Matos, José Nuno. 2012. "Empregabilidade e identidade na era do capitalismo cognitivo. [Employability and identity in the era of cognitive capitalism]" In Classes, Politicas e Culturas de Classe: Capital, Trabalho e Classes Intermédias, edited by Manuel Carlos Silva and João Valente Aguiar, 53-62. Vila Nova de Famalicão: Edições Húmus.

Mayer, Margit. 2013. "First World Urban Activism." City: Analysis of Urban Trends, Culture, Theory, Policy, Action 17 (1): 5-19. doi:10.1080/13604813.2013.757417.

Mendes, Luís. 2008. "Gentrificação e a cidade revanchista: que lugar para os movimentos sociais urbanos de resistência? [Gentrification and the revanchist city: what place for urban social movements of resistance?]" Fórum Sociológico 18 (2): 21-28.

Menezes, Marluci. 2012. "Sobre a intervenção socio-urbanística na cidade consolidada. O caso da Mouraria em Lisboa. [About the socio-urban intervention in the consolidated city. The case of Mouraria in Lisbon]", Paper presented at Jornadas LNEC - cidades e desenvolvimento, Lisbon, June 18-20.

Norris, Pippa. 2002. Democratic Phoenix: Reinventing Political Activism. Cambridge: Cambridge University Press.

Oliveira, Márcio Piñon. 2000. “Geografia, globalização e cidadania. [Geography, globalization and citizenship]" Terra Livre 15: 155-164.

Parazelli, Michel. 2001. "Penser géographiquement l’exercise de la citoyenneté ." [Geographically think about the exercise of citizenship]." In Géographie et société: ver une géographie citoyenne, directed by Suzanne Laurin, Juan-Luis Klein, and Carole Tardif, 271-287. Québec: Presses de l'Université du Québec.

Peck, Jamie. 2012. "Austerity Urbanism." City: Analysis of Urban Trends, Culture, Theory, Policy, Action 16 (6): 626-655. doi:10.1080/13604813.2012.734071.

Pereira, Inês. 2011. "Consumos Contestados. [Contested consumptions]" Sociologia Online - Revista da Associação Portuguesa de Sociologia 4: 61-71.

Pocock, J. G. A. 1995. “The Ideal of Citizenship Since Classical Times.” In Theorizing Citizenship, edited by Ronald Beiner, 29-52. Albany: State University of New York Press.

Purcell, Mark. 2003. "Citizenship and the Right to the Global City: Reimagining the Capitalist World Order." International Journal of Urban and Regional Research 27 (3): 564-590. doi:10.1111/14682427.00467.

Purcell, Mark. 2006. "Urban Democracy and the Local Trap." Urban Studies 43(11): 1921-1941. doi: $10.1080 / 00420980600897826$.

Purcell, Mark. 2008. Recapturing Democracy: Neoliberalization and the Struggle for Alternative Urban Futures. New York: Routledge.

Purcell, Mark. 2013. The Down-deep Delight of Democracy. Oxford: Wiley-Blackwell.

Rancière, Jacques. 1999. Disagreement: Politics and Philosophy. Minneapolis: University of Minnesota Press. 
Rogers, Alisdair. 2000. "Citizenship, Multiculturalism, and the European City." In A Companion to the City, edited by Gary Bridge and Sophie Watson, 282-291. Oxford: Blackwell.

Rolnik, Suely. 2010. "Políticas da hibridação: evitando falsos problemas. [Hybridization policies: avoiding false problems]" Cadernos da Subjectividade 14: 14-21.

Scott, James C. 1998. Seeing Like a State: How Certain Schemes to Improve the Human Condition Have Failed. New Haven: Yale University Press.

Staeheli, Lynn. 2011. "Political Geography: Where’s Citizenship?” Progress in Human Geography 35 (3): 393-400. doi:10.1177/0309132510370671.

Staeheli, Lynn. 2008. "Citizenship and the Problem of Community." Political Geography 27: 5-21. doi:10.1177/0309132510370671.

Standing, Guy. 2011. The Precariat: The New Dangerous Class. London: Bloomsbury Academic.

Stevenson, Nick. 2003. "Cultural Citizenship in the 'Cultural' Society: A Cosmopolitan Approach." Citizenship Studies 7 (3): 331-348. doi:10.1080/1362102032000098904.

Traquino, Marta. 2011. "Considerações sobre uma arte fora do mercado. [Considerations about an art out of the market]" In Arte Agora. Pensamentos enraizados na experiência, organized by Sofia Neuparth and Christine Greiner, 119-123. São Paulo: Annablume.

Zizek, Slavoj. 2006. Elogio da Intolerância [Praise of Intolerance]. Lisboa: Relógio D’Água.

Zukin, Sharon. 1995. The Cultures of Cities. Cambridge: Blackwell. 